\title{
COLLAPSING STRUCTURES OF LIFE AND DEATH IN MIKE MCCORMACK'S SOLAR BONES
}

\author{
ESTRUCTURAS FRACASADAS DE VIDA Y MUERTE \\ EN SOLAR BONES, DE MIKE MCCORMACK
}

\author{
WITZ PIETRZAK \\ University of Lodz \\ witpietrzak@wp.pl
}

\section{Abstract}

In the present essay I argue that that Mike McCormack's acclaimed latest novel Solar Bones (Brit. 2016, USA 2017) thematises two impulses: on the one hand, the narrator, Marcus Conway, is seeking an order and structural coherence to his world, an order that throughout assumes a distinctly religious tint; on the other hand, the novel features various images of collapse of structures, ranging from the economic system all the way to actual buildings, all of which thwart his efforts. It is those twin movements, towards order and chaos, that reveal an association with Heidegger's idea that only by becoming aware of death as one's sole personal mode of life, does one begin to apprehend the essential structure of life, even if the glimpse of that structure is only ever available in its constant deferral.

Keywords: Mike McCormack, Solar Bones, Irish contemporary fiction, Martin Heidegger, collapsing structures.

\section{Resumen}

Este ensayo pretende demostrar que Solar Bones, la aclamada novela de Mike McCormack recientemente publicada (Reino Unido 2016, EEUU 2017), se articula a caballo entre dos impulsos: por un lado, el narrador, Marcus Conway, 
trata de encontrar un orden y una coherencia elemental para su mundo, en una búsqueda que adopta un matiz característicamente religioso; por otro lado, la novela muestra numerosas imágenes del fracaso del sistema, desde el orden económico hasta edificios reales, que frustran sus esfuerzos. A través de esos movimientos que simultáneamente tienden hacia el orden y hacia el caos se revela una relación con el postulado de Heidegger según el cual, cuando uno es consciente de la muerte como el único modo de vida puede empezar a percibir la estructura esencial de la ésta, incluso si dicho orden únicamente es perceptible a través de su constante aplazamiento.

Palabras clave: Mike McCormack, Solar Bones, ficción irlandesa contemporánea, Martin Heidegger, estructuras fracasadas.

In his acclaimed latest novel Solar Bones(Brit. 2016, USA 2017), Mike McCormack ponders such notions as the completion and brevity of life and its purposefulness. Reviewers have been quick to put McCormack's latest novel in the company of modernist avant-gardists James Joyce and Virginia Woolf (Riker 2018). Martin Riker prefaces his review with a brief note that "Modernism was about many things, but largely it was about fragmentation. The world had cracked, and artists had noticed" (Riker 2018). While he goes on to acknowledge that McCormack's novel "is a wonderfully original, distinctly contemporary book, with a debt to modernism but up to something all its own" (Riker 2018), there is a general feeling that Solar Bones has taken its rightful place beside Eimer MacBride's A Girl is a Half-Formed Thing - the first winner of the Goldsmiths prize for innovative fiction, which Solar Bones won in 2016- as another great Irish experimental novel that confirms Ireland's innovative pedigree, which goes all the way back to Joyce. Interestingly enough, McCormack does not cut himself off from what he calls "our [the Irish] Mount Rushmore" (in Boland 2016): Joyce, Flann O'Brien and Samuel Beckett. He does, however, admit that " $[\mathrm{m}] \mathrm{y}$ generation were a bit wary of picking up the challenge those old fellows had laid down for us", stressing nonetheless: "Now I see it not as a challenge, but a license. Beckett and Joyce and Flann are giving me the quest: go forth and experiment" (in Boland 2016). When asked about his influences, McCormack points out that "stylistically, the book I always refer to is The Autumn of the Patriarch by Gabriel García Márquez- it's the best example of how to write long sentences", the point being, of course, that Solar Bones is just one long, scattered sentence (in Boland 2016). But more importantly, McCormack says in the same interview, "[ $\mathrm{t}]$ he things that came to my mind when I was writing were essays by Martin Heidegger. The style of those 
essays was influential in that Heidegger created a logical sense out of repetition, a repetition of swirling rhythms. They're the biggest influence on Solar Bones" (in Boland 2016).

McCormack had acknowledged his debt to Heidegger in an earlier interview, where he said he had read Heidegger "and his ideas on technology" (O'Malley 2012) but it appears that whereas The Question Concerning Technology (1954, Eng. 1977) underpins some of the stories in Forensic Songs (2012), Solar Bones is more taken with Heidegger's delineation of death as the fundamental structure of Dasein. The present essay sets out to show that the latter novel is strung between two impulses: on the one hand, the narrator, Marcus Conway, is seeking to assert an order and structural coherence to his world, with his search assuming a distinctly religious tint; on the other, the novel features numerous images of collapse of structures, from the economic system all the way to actual buildings. It is those twin movements, towards order and chaos all at once, that reveal an association with Heidegger's thesis that only by becoming aware of death as our sole personal mode of life, does one begin to apprehend the essential structure of one's life even if the glimpse of that structure is only ever available in its constant deferral.

\section{Ghostly Structures}

Solar Bones begins on November 2, when Conway recalls hearing the Angelus bell: "The bell/ the bell as/ hearing the bell as/ hearing the bell as standing here/ the bell being heard standing here/ hearing it ring out through the grey light of this/ morning, noon or night" (McCormack 2017: 1). This end-stopped opening suggests a prose poem, as Ian Samson notes (2016), an implication not far removed from McCormack's avowed plan; as he suggested in an interview, "Poetry aspires to say the unsayable, and there's a degree of that in Solar Bones" (Wallace 2018). The reader is led to assume that Marcus is a ghost, remembering various instances from his life until he reaches the moment of his demise, most likely from a heart attack. Given that the novel is set on All Souls' Day, the inevitable context is Yeats's "All Souls' Night" (1920), a poem that celebrates "mummy truths" (Yeats 1996: 234 ) that the poet-seer has come to know through his mediumistic wife's automatic writing sessions. In A Vision (1937), Yeats delineates some of those "mummy truths", explaining that a soul, which he dubs the Spirit, passes through six stages on its way to reincarnation, noting that in the second stage, which is called the Dreaming Back, "the Spirit is compelled to live over and over again the events that had most moved it; there can be nothing new, but the old events stand forth in a light which is dim or bright according to the intensity of the passion that accompanied them" (Yeats 1969: 226). This is an apt description of Marcus's 
condition in that his narrative seems also to revisit the most passionate, or at least the most intense, moments of his life: the fraught relationship with his father, his wife's illness, his daughter's artistic achievements and his son's departure to Australia, a painful reminder throughout the novel of the abyss that separates Marcus from his loved ones, even if there are also instances when Marcus recalls happy moments of communion with his father and wife. Also, the fact that the narrative trails away without a full stop to mark the end of the sentence may be taken to indicate the recurrence of the narrative, in line with Yeats's insistence that the Spirit lives through the passionate moments over and over again.

Yeats's discussion of life after death matters insofar as, for him, death instigates the process of empting of the Spirit that results in utter loss of memory of the past incarnations; only after Purification is finished, may it pass on to the final stage of Foreknowledge, during which it "must substitute the next incarnation [...] for that form of perfection" which is achieved in the completion of Purification (Yeats 1969: 234). Despite the undoubtedly esoteric nature of Yeats's writing, it casts light on what appears to be Marcus's aim, as the novel leads us to speculate. He strives to trace his life to an unravelling of loose threads so that it all makes sense to him. However, what distinguishes Conway from Yeats's ghosts in a poem like "All Souls' Night" is the fact that whereas they are believed to possess knowledge denied to the living, the narrator of Solar Bones is riddled by confusion, internal tensions and ambiguities, which zero in on the conflict between structure and its collapse.

Reflecting on his job as an engineer, Marcus concludes that there is a part of him that "needs to have faith in things" and so engineering becomes for him "a religious vocation with its own rituals and articles of faith not to mention a reckoning in some vaulted and girdered hereafter where engineer's souls are weighed and evaluated after a lifetime's wear and tear in the friction of this world" (McCormack 2017: 169). This insight is corroborated by his idea of the world as a coherent structure conceived by God, the ultimate engineer; as Marcus muses:

$[\mathrm{T}]$ he whole world [was] built up from first principles, towering and rigid as any structural engineer might wish, each line following necessarily from the previous one to link heaven and earth step by step, from the first grain of the first moment to the last waning scintilla of light in which everything is engulfed in darkness, the engineer's dream of structured ascent and stability bolted into every line of its [the Catechism's] fifty pages, so carefully laid out that any attentive reading of it should enable a man to find his place with some certainty in the broadest reaches of the world, a tower of prayer to span heaven and earth and something which a part of me has never grown out of or developed beyond[.] (76)

Marcus hankers after a vision of eternal completeness and coherence, of which his profession is just an extension. As his son, Darragh, tells him, “it's well known that 
engineers picked up where God left off" (McCormack 2017: 169). In light of Marcus's belief in the existence of structures, it is little surprising that he discovers patterns and coherences all about him. The motifs that recur throughout the novel function like the scaffolding by means of which he tries to maintain a grip on reality. Being up to date with news is more than just an everyday activity, for Marcus confides: "I was one of those men who had always structured his days around radio news bulletins right from the moment I got up in the morning and stood with my mug of tea in the kitchen listening to the sea area forecast with its sing-song litany of names from around the coast" (111). The word "structure" scuttles across the narrative with an almost obsessive regularity, as Marcus alludes to "political structures" (34), the "protective structure of a democracy" (33), and credits himself with an "engineer's sense of structure" (67). This is a running theme in McCormack's fiction in general, with a particularly apt evocation in Notes from a Coma (2005), in which the main protagonist, J.J. O'Malley is said to see "signs everywhere", which he then weaves "together into a kind of world view" (McCormack 2005: 46).

Like J.J., Marcus also entertains a world view that communicates to him a sense of order and balance; so much so that, for example, he discovers an internal logic in a story his wife tells him of a Mongolian tribe in which there is a woman who "walks backwards and talks backwards and rides her horse backwards, she gets up in the middle of the night to eat her dinner and she goes to bed when everyone around her is beginning their day" because "it's their belief that if everyone is walking and talking and doing things in the same direction then there is real danger that the whole world will tip over, so one person is needed to work the opposite way to keep the world balanced" (McCormack 2017: 67). To that Marcus responds with an immediate judgement: "that makes sense, it's basic engineering, any load bearing structure will topple over if it doesn't have balancing counterweight, cranes will topple over if they are not properly weighted" (67). Although frequently hidden behind the veil of science, Marcus's world view is underlain with the conviction that mechanics only confirms the divine logic that went into the creation of the universe.

There is a distinct echo here of Thomas Aquinas's five proofs of the existence of God, especially the first, the argument from motion. Aquinas argues that since everything in the world is in motion, by which he means change, something must have first propelled it: "For motion is nothing else than the reduction of something from potentiality to actuality. But nothing can be reduced from potentiality to actuality, except by something in a state of actuality" (Aquinas 1990: I.3.2). Marcus literally picks up the same line of thinking when he discusses pouring concrete for the foundations of a building. In a flight of fancy, he says: 


\section{Witz Pietrzak}

the timing and cooperation needed and the way the rising and spreading tide of concrete itself demarks, as no other stage in the building process can, the actual from the theoretical, makes the whole thing real in a way that site-clearing or the digging out of the foundation itself can never do. (McCormack 2017: 167)

Pouring concrete represents the crucial moment in "any structure's transition" from theoretical, or what Aquinas refers to as potential, to actual. On a wider scale, Aquinas's proof, like the remaining ones and indeed, the entirety of Summa Theologica (XIII c.), indicates a grand design of things at the core of which lies the supreme intellect we understand to be God (see Elders 1993: 231-238). It is this belief in the existence of an order beyond the chaos of reality that helps Marcus endure the difficult period when his wife suffers from bacteria poisoning; when after an excruciating bout of sickness she begins to feel markedly better, he comes to "[experience] a shameless, rising joy in my heart as if finally, for the first time in a long while I was hearing something good, something which was not of this world's raucous tumult but which spoke of that harmonic order which underlay everyone and everything" (McCormack 2017: 199). The joy he feels is thus as much a relief at Mairead's improving condition as it is the fruit of his regained intellectual conviction that there is an order to the world.

\section{Collapsing Structures}

Marcus's search for structures, whether premeditated or randomly discovered, is juxtaposed with images of collapse of order, which threaten to overwhelm him and his family. The novel opens with an evocation of the financial crisis that struck the world following the declaration of insolvency by the Lehman Brothers on 15 September, only a little over a fortnight before the novel takes place. For a man so trusting as Marcus is of the idea that the world follows a prescribed pattern, the 2008 crisis surely was a deadly blow. The post-crisis analyses of the causes for Ireland's dramatic recession invariably stress the dependence on foreign, mainly US, investment that was spurred by favourable corporate tax, the main factor in Ireland's economic boom in the 1990s (see Whelan 2014). In addition, Donovan and Murphy have noted that the financial crisis was preceded by a sequence of downturns, at the beginning of which lay the collapse of the property market (2014: 7). This particular failure wold be an especially stinging fact for an engineer like Marcus, who would have contributed in no small measure to the increase in the asset bubble, as it was triggered by the spike in infrastructure development and overhaul. His first evocation of the crisis stresses its unstable and unpredictable nature: "more abstract indices are rising and falling to their own havoc" (McCormack 2017: 7) while "our prophets deranged/ and coming towards us wild-eyed and smeared with shit, ringing a bell, seer and sinner at once while 
speaking some language from the edge of reason whose message would translate into plain words as/ we're fucked" (8). The religious language Marcus employs points to the divine dimension of the economic catastrophe. In his recounting, November 2008 was the year of Ireland's reckoning on a par with an apocalypse: "the indices and magnitudes of a new cosmology, the forces and velocities of some barren, inverse world - a negative realm that, over time, will suck the life out of us" (7). The world that has arrived following the onset of the recession is characterised by the toppling of the order that appeared to be unshakeable, both in the sense of global financial stability and the ontological certitude.

The ripples of the crisis extend far beyond the economy. Even though Marcus recognises the financial threat, noting that it may still have "a domino effect across several linked economies" like Germany and France (McCormack 2017: 13), he remains puzzled by the ease with which the metaphorical layer of the word "collapse" is employed to talk of the volatile situation: "something that never was has finally collapsed/ or revealed itself to be constructed of air before eventually/ falling to ruin in that specific way which proved it never existed even if all around us now there is that feeling of something massive and consequential having come asunder" (13). Marshall Berman's idea of modernity (seen as a historical process that, in some respects, goes back to the Renaissance) as the time when all that is solid melts into air, which for him triggers the necessity that one be "at home in the maelstrom" of social and aesthetic change as well as, sometimes heedless, technological advancement (1988: 345), returns to plague Marcus. He is a man of a scholastic persuasion coupled with a renaissance belief in engineering as the path to the betterment of mankind and so he finds himself alienated from what Berman called the "maelstrom of modernity". For Marcus, the stability of the world as a structure inheres in the tangibility of tools and their products; as a result he is bewildered to realise that "the idea of collapse/ needs some expanding beyond the image of things toppling and falling down" (McCormack 2017: 23). This initial inkling is unpacked in a passage that merits an extended quotation:

$[\mathrm{P}]$ lunging masonry, timber, metal, glass - the engineer's concept of collapse, buildings and bridges staggered before crumbling to the ground and raising up clouds of dust because, from what's written here about the global economic catastrophe, all this talk of virus and contagion, it is now clear to me that there are other types of chaos beyond the material satisfactions of things falling down since, it appears, out there in the ideal realm of finance and currency, economic constructs come apart in a different way or at least

in ways specific to the things they are, abstract structures succumbing to intensely rarefied viruses which attack worth and values and the confidence which underpin them, swelling them beyond their optimal range to the point where they overbalance and eventually topple the whole thing during the still hours of the night so that we wake the following morning to a world remade in some new way unlikely to be to our benefit[.] (24) 
This is the condition of late modernity that was anticipated by numerous writers, most importantly, though, by Don DeLillo in Cosmopolis (2003). In the novel, the banking prodigy Eric Packer believes that the global stock exchange "charts" (McCormack 2017: 37), the fluctuations of markets may seem chaotic and unpredictable but out of the chaos a pattern must always emerge; it is just that the pattern does not emerge and Packer loses his fortune right before he loses his life. Packer's hubris leads to his doom, for he fails to appreciate the complexity of the financial markets which no longer respond to analytical patterns. Unlike Packer, Marcus knows that "economic constructs come apart in a different way", always outstripping our models of prediction. Yeats diagnosed the centre failing to hold and Marcus witnesses a similar, albeit less perceptible, collapse of the world-order once considered unchangeable.

While the economy collapses in a metaphorical sense, there are numerous architectural structures in Solar Bones that are shown to come apart as well. Of the many dilapidated buildings, it is Marcus's father's house that is consistently evoked as a space of decrepitude after the mother as death: "no fire or heat on in the house anymore so that it got damp and filthy with black mould growing down the walls and nothing but the smell of piss" (McCormack 2017: 145). The world of the novel is rife with such deteriorating structures, including the corroding pipeline, which is the likely cause of the water contamination that results in the city-wide poisoning. Run-down buildings also betoken the aura of general collapse, especially when Marcus appears to be hopeful for the future. Towards the end of the novel, as he rejoices in his wife's recuperation driving to town for some medicines, Marcus passes by a hotel, a place of some renown in the past, which is now ramshackle:

the Imperial Hotel standing there on the left behind its high, blistered walls, filthy and eyeless in its broken grounds, derelict for two decades now inside those scrolled iron gates, a sorry sight, the more so because no one knows properly how or why it came to such dilapidation at the precise moment when its tennis courts and swimming pool made it the most glamorous spot in the whole region. (209)

For an engineer so keen to see structures prevail over the chaos of reality, the many sights of material deterioration indicate that the abstract collapse, represented by the failure of the banking system, finds its correlate in the thingly world.

This vision of fall is, significantly enough, not only derived from the outside but also is shown to be situated inside Marcus's mind, as his thoughts and the narrative along with them, wander off into byways of reveries and idle musings, neither of which bears any relation to the advancement of the plot:

if given its head

the mind in repose, unspooling to infinity, slackening to these ridiculous musings which are too easily passed off as thought, these glib associations, mental echoes which reverb with our anxiety to stay wake and wise to the world or at least attentive to as much of its circumstances as we can grasp[.] (McCormack 2017: 143) 
Although it is in these "glib" musings that some of Solar Bones's most strikingly lyrical passages — such as the one just cited - appear, Marcus resents them, as they represent for him a depredation of yet another structure, the structure of thought. In a striking connection of the figurative and literal meanings of the word "structure", he conceives of them as akin to his father's derelict house from which

all its pulses and rhythms have been swept [...] so that time itself is legless here with all things, myself included, suspended in a kind of stalled duration, an infinitely extended moment spinning like an unmeshed gear, a stillness within which no knife will blunt, no mirror will tarnish, no paint will peel, no hunger will grasp my belly nor will I ever have to shave. (McCormack 2017: 211)

It is in this reverie that Marcus provides us with a most direct suggestion that he lives in the limbo, suspended timeless and still. There is no Aquinasian order to Conway's world, for it is the realm of slow devastation in which structures come apart, "The falcon cannot hear the falconer" (Yeats 1996: 187) and no centre can hold as the dead are floating around knowing little of their own condition or, indeed, of those "mummy truths" with which Yeats vested the spirits in "All Souls' Night” (1996: 230).

The image of the house and Marcus's own mind “suspended in a kind of stalled duration" represents what appears to be the culmination of the overarching tension in the novel. The structures that Marcus has sought to assert in a single breath, in a single sentence, collapse all around him, just as the sentence should better be understood as a series of paratactically juxtaposed clauses that end in suspension marks. The local area, which he has diligently strived to build, is a shambles, with the economic situation remaining precarious and politics being a matter of beguiling people into casting their votes in favour of the candidate who claims the greatest staying power in the popular imagination via the media and public appearances. Finally, even the town's pipelines and the erection of the new school reveal that engineering is no answer to the community's problems. In view of the situation Marcus witnesses, it becomes clear that his essentially religious yearning for an order of things leads him to a false perception of the notion of order and how it applies to his own life. It is in the images of persistent collapse and confusion that thwart Marcus's efforts at unravelling a structure to his life that the novel gives way to what Heidegger has discussed as man's condition of "not-yet".

\section{Heidegger's "Not-Yet" and the Fact of Death}

Division two of Being and Time features the famous exploration of death as the "phenomenon of life" (Heidegger 2001: 284) to be understood as the horizon of 
existence: "Death is the possibility of the absolute impossibility of Dasein. Thus death reveals itself as that possibility which is one's ownmost, which is non-relational, and which is not to be outstripped [unüberholbare]. As such, death is something distinctively impending" (294, emphasis in original). This is a fundamental insight into the constitution of Dasein as an ontological structure of "care" [Sorge]. For Heidegger, "care" represents the crucial mode of being-in-the-world conceived as "ahead-of-itself-Being-already-in-(the-world) as Being-alongside (entities encountered within-the-world)" (237). In this dense and much-discussed passage (for a lucid reading see Macann 1993: 85-96), Heidegger posits that one's existence in the world is always already a foundation of one's future development; this is the condition of "thrownness", whereby Dasein "is sucked into the turbulence of the 'they's' inauthenticity" (Heidegger 2001: 223). One is in the world prior to being aware of that fact. Moreover, one exists in the world alongside others (Heidegger's “they”), among whom Dasein's death is concealed: "They say, 'Death is certain'; and in saying so, they implant in Dasein the illusion that it is itself certain of its death" (301) while in fact by stripping death of the personal connection, "they" hide from Dasein its ownmost potential. By contrast, only if Dasein comes to "care" for its death as the concluding phenomenon of life, will it conceive of life as striving after structural completeness.

Thus, Heidegger suggests that Dasein is a structure consisting of "thrownness", which is concerned with its past, "ahead-of-itself-Being-already-in-(the-world)", which is forward-looking, and "being-alongside", which is concerned with the present (Pacelli 2017: 246); for this temporal structure of Dasein to be coherent, death must be "cared" for all throughout life. However, being a potentiality that Dasein cannot fully experience, death also represents a horizon of life that is always apprehended as it is receding: "In Dasein, as being towards its death, its own uttermost 'not-yet' has already been included" (Heidegger 2001: 303). The only way Dasein can make its own structure of being cohere is by understating its beingtowards-death as a "not-yet". Therefore the paradox lies in the fact that structural completion is only possible as a continuous "care" for what remains perpetually elusive. In his essay on Kafka's parable "Before the Law" featured in The Trial, Derrida notes that Kafka's guardian who tells the man wanting to enter the palace of law that he cannot enter, at least "not yet", represents the "potency [of] différance, an interminable différance, since it lasts for days and 'years', indeed, up to the end of (the) man. Différance till death, and for death, without end because ended" (Derrida 1991: 204). This aptly captures the paradox that Heidegger implies in paragraph 52 of Being and Time, for the deferral of the completion of Dasein's ontological structure is what at the same time endows it with the potential for conceiving of itself as possessing a structure. While for Derrida the deferral, the play of différance, marks the condition of writing and thinking as endless pursuits 
-what in the same essays he calls "(no) more law and (no) more literature" (Derrida 1991: 215)—, for Heidegger the "not-yet" is a future-oriented potential that both allows Dasein the space for self-creation and endows it with a conception of coherence of whatever it undertakes.

What Heidegger shows is that only by coming to terms with the fact that the ontological structure must collapse, can one begin to perceive life as a structure. Where Derrida lays emphasis on the continuous deconstruction of ontological, metaphysical and epistemological patterns, as exemplified in "Before the Law", Heidegger stresses the paradoxical nature of being-in-the-world that demands destruction in order to imagine a potential coherence. It is this insight that seems to lie behind McCormack's admission that Heidegger's later style, which seeks to overcome the language's inherent barrier to expression, was an influence when he wrote Solar Bones. This is evidenced by Marcus's hankering after an order, a structure that would tie together Heaven and Earth, life and death, in a single full sentence. This is where the formal experimentalism of the novel contravenes Marcus's declared aim, as the unfolding sentence comes to represent an instant of blatant forgetting of finality, of forgetting one's own death. Just as Yeats's ghosts in the initial stages of life after death fail to realise that they are dead, so Marcus is oblivious, except for the few moments of premonition, to his being a ghost. Moreover, seeking to trace his life to a coherent formula, he defers the realisation that what he is trying to put off is the fact of his own death. Bearing in mind Heidegger's understanding of death as ownmost potentiality of Dasein, it transpires that the collapse of all structures that Marcus witnesses throughout the novel summons him to accept his own demise. In his desire for order, which he infuses with an Aquinasian understanding of God and His manifestations in the world, Marcus occludes the actual structure that underpins his existence.

In view of Heidegger's theorisation of death, Marcus's narrative may best be viewed as expressing final stages of conscious being; and yet in spite of being conscious, Marcus, by prolonging the completion of his last sentence through veering and plunging into reveries, refuses to acknowledge what the dissipating world all about him evokes: that the only structure there is to his world is that of his ownmost existence whose defining point is death. This appears to be the idea behind the sole use of the titular phrase in the novel, which comes after Marcus enters into one of his musing moods following the ended Skype conversation with his son:

I watched the screen cloud to a fizzy interference as it shut down, leaving the room to dark silence and a burnt feeling behind my eyes as if the light from the monitor had scalded them to the core, the kind of feeling you imagine you would have just before the world goes up in flames, some refined corrosion eating away at the rods and cones, collapsing their internal structure before they slope out of their sockets and run down your cheekbones, leaving you standing hollow-eyed in the middle of some 
desolation with the wind whistling through your skull, just before the world collapses mountains, rivers and lakes acres, roods and perches into oblivion, drawn down into that fissure in creation where everything is consumed in the raging tides and swells of non-being, the physical world gone down in flames mountains, rivers and lakes and pulling with it also all those human rhythms that bind us together and draw the world into a community, those daily rites, rhythms and rituals upholding the world like solar bones, that rarefied amalgam of time and light whose extension through every minute of the day is visible from the moment I get up in the morning and stand at the kitchen window with a mug of tea in my hand [.] (McCormack 2017: 69-70)

McCormack's brilliantly evocative prose reaches here a crescendo of imaginary flourish, as Marcus invokes a vision of the combustion of the world punctuated by the serene refrain of "mountains, rivers and lakes". The passage, which comes a third into the novel, represents an acute imagining of Heidegger's delineation of death, as Marcus suggests that the "solar bones", those "rites, rhythms and rituals", submerge him in "that rarefied amalgam" of everydayness, which Heidegger denotes by the term "falleness", whereby "Dasein has [...] fallen away [abgefallen] from itself as an authentic potentiality for Being its Self, and has fallen into the "world" (Heidegger 2001: 220). Marcus drowns in the inauthenticity of "non-being" as he also entertains inklings of those "solar bones" "collapsing their internal structure". As the vision crumbles, the essential structure of death, founded on the "not-yet", shines through the debris, reminding Marcus that it is solely on the condition he face up to his own end that he can discover what he yearns for: the order of the world of which he is now a fading part.

\section{Works Cited}

Aouinas, Thomas. (1265-1274) 1990. Summa Theologica Vol. I. London: Encyclopaedia Britannica.

Berman, Marshal. 1988. All that is Solid Melts into Air: The Experience of Modernity. London: Penguin.

Boland, Stephanie. 2016. "Interview with Mike McCormack: 'British Fiction is Dominated by an Intellectual Conservatism'". New Statesman (November 7). <https://www.newstatesman. com/culture/books/2016/11/mike-mccormackbritish-fiction-dominated-intellectualconservatism>. Accessed May 5, 2019.

DeLIlto, Don. 2003. Cosmopolis. New York: Scribner.

DerRidA, Jacques. 1991. Acts of Literature. Ed. Derek Attridge. New York: Routledge.

Donovan, Donal and Antoin E. Murphy. 2014. The Fall of the Celtic Tiger: Ireland and the Euro Debt Crisis. Oxford: Oxford U.P. 
ELDERS, Leo J. 1993. The Metaphysics of Being of St. Thomas Aquinas: A Historical Perspective. New York: E.J. Brill.

HeIdegger, Martin. (1954) 1977. The Question Concerning Technology and Other Essays. Trans. W. Lovitt. New York: Garland.

Heidegger, Martin. 2001. Being and Time. Trans. J. Macquarrie and E. Robinson. Oxford: Blackwell.

McCormack, Mike. 2005. Notes from a Coma. London: Jonathan Cape.

McCormack, Mike. 2012. Forensic Songs. Dublin: The Lilliput Press.

McCormack, Mike. 2017. Solar Bones. New York: Soho.

MACANN, Christopher. 1993. Four Phenomenological Philosophers: Husserl, Heidegger, Sartre, Merleau-Ponty. London: Routledge.

O'Malley, J.P. 2012. "Cult Status: An Interview with Mike McCormack". The Spectator (June 26). <https://blogs.spectator.co.uk/2012/10/ cult-status-an-interview-with-mikemccormack/>. Accessed May 5, 2019.

PACELLI, Albert Peter. 2017. Being and Intelligibility. Eugene, OR: Wipf and Stock.

RIKER, Martin. 2018. “Interview with Mike McCormack: A Stylistically Daring Novel
Considers Fundamental Questions". The New York Times (January 5). <https://www. nytimes.com/2018/01/05/books/review/solarbones-mike-mccormack.html>. Accessed May 5, 2019.

SAMSon, Ian. 2016. "Solar Bones by Mike McCormack Review - An Extraordinary Hymn to Small-Town Ireland". The Guardian (June 4). <https://www. theguardian.com/books/2016/jun/04/solarbones-by-mike-mccormack-review $>$. Accessed May 5, 2019.

Wallace, Arminta. 2018. "I Had the Canny Idea of Writing a Long Sentence instead of a Book': Interview with Mike McCormack". The Irish Times (May 23). <https://www.irishtimes. com/culture/books/mike-mccormack-i-hadthe-canny-idea-of-writing-a-long-sentenceinstead-of-a-book-1.2654939>. Accessed May 5, 2019.

WHELAN, Karl. 2014. "Ireland's Economic Crisis: The Good, the Bad and the Ugly". Journal of Macroeconomics 39 (1): 424-440.
Collier Books.

Yeats, W.B. 1996. The Collected Poems of W.B. Yeats. Ed. Richard J. Finneran, New York: Scribner. 